\title{
Association of Hypertension and Smoking with Ischaemic Stroke
}

\author{
K Kirtania ${ }^{1}$, N Sultana ${ }^{2}$, S A hmed2, A Khatun 3 \\ ${ }^{1}$ Dept of Biochemistry, J ahurul Islam M edical College, Bazitpur, Keshorgonj \\ ${ }^{2}$ Dept of Biochemistry, Dhaka Medical College, Dhaka \\ IInstitute of Epidemiology, Disease Control and Research, Dhaka
}

\begin{abstract}
Hypertension is one of the most important modifiable risk factors for ischemic stroke. Cigarette smoking is a risk factor for atherosclerotic disease. There is a strong relationship between hypertension and cigarette smoking with ischaemic stroke. A case control study was undertaken to see the association of hypertension and cigarette smoking with ischaemic stroke. The study was done from January to December 2009 in the Department of Biochemistry, Dhaka M edical College, D haka. A total of 60 subjects were selected as study population. A mong them 30 were diagnosed case of ischaemic stroke and 30 were age-and sex-matched control subjects. It was found that $60 \%$ patients of case group and $20 \%$ respondents of control group were hypertensive and diffrence was significant. Study showed that $56.66 \%$ of cases and $53.33 \%$ of controls were smoker and the findings were insignificant. The mean duration of smoking was $27.41 \pm 2.98$ years in cases and $15.63 \pm 2.85$ years in controls which was significant. The study suggests that hypertension is significantly associated with ischaemic stroke and longer duration of smoking also associated with ischaemic stroke.
\end{abstract}

Key W ords: Ischaemic Stroke, Cigarette Smoking, Hypertension

\section{Introduction}

A fter coronary artery disease and cancer, stroke is the third commonest cause of death in he developed countries 1 . It predominates in the middle and late years of life. Traditional risk factors for stroke include advanced age, hypertension, diabetes mellitus, heart disease, elevated serum cholesterol, obesity, cigarette smoking, lower socioeconomic class and drugs use and abuse2,3. Hypertension is one of the most important modifiable risk factors for ischaemic stroke. Hypertension indicates a risk of stroke when hypertension is defined as systolic blood pressure $\geq 160 \mathrm{~mm} \mathrm{Hg}$ and / or diastolic lood pressure $\geqslant 95 \mathrm{~mm} \mathrm{Hg}^{4}$. Cigarette smoking increases the risk of ischaemic stroke nearly two times; with a clear dose -response relation. Risk of ischemic stroke is more in the current smoker than the ex-smoker. The mechanism by which smoking is thought to increase the likelihood of ischaemic stroke include increased fibrinogen level and platelet adhesiveness and reduced cerebral blood flow mainly due to atheroma formation and higher blood viscosity in chronic smoker5. The present study was carried out to see the association of hypertension and cigarette smoking with the ischemic stroke.

\section{Subjects and Method}

The study was carried out in the Department of Biochemistry, Dhaka Medical College, Dhaka during the period of J anuary to December 2009. The patients were taken from the Department of Neurology and M edicine U nit of Dhaka M edical College Hospital (DMCH). Ischaemic stroke patients were considered as case and the control were age-and sex-matched volunteers. Cases were the patients clinically suffered from ischaemic stroke confirmed by computerised (CT) tomography scan of brain attending the 
Department of Neurology and different Medicine Units of DMCH during the study period. In this study sample size were taken as 60 . Thirty patients with ischaemic stroke were taken as cases among which 21 were male and 9 were female; and 30 healthy volunteers were taken as controls among which 21 were male and 9 were female. Data were analyzed by computer with the help of SPSS version 12 software package. All data were recorded systematically in a data collection sheet. Categorical variables were analyzed by using chi square test. For all the statistical analysis 2tailed ' $p$ ' values $<0.05$ were considered as significant.

\section{Results}

In both groups (case and control), $30 \%$ were in $5^{\text {th }}$ decade, $56.66 \%$ were in $6^{\text {th }}$ and $7^{\text {th }}$ decade and $13.33 \%$ were in $8^{\text {th }}$ decade of their lives. In the case group M ean ( \pm SD) of ages was 65.26 $( \pm 6.68)$ years and in the control group it was $65.10( \pm 7.04)$ years. (Table-I).

Table I : Age distribution of case and control

\begin{tabular}{lll}
$\begin{array}{c}\text { Age (years) } \\
(\mathrm{n}=30) \\
\text { number }(\%)\end{array}$ & $\begin{array}{c}\text { Group-I } \\
(\mathrm{n}=30) \\
\text { number }(\%)\end{array}$ \\
\hline$<609(30.0) *$ & \multicolumn{2}{c}{$9(30.0)$} \\
$60-80$ & $17(56.66)$ & $17(56.66)$ \\
$>80$ & $4(13.33)$ & $4(13.33)$ \\
M ean \pm SD & $65.26 \pm 6.68$ & $65.10 \pm 7.04$ \\
Group-I = Case , Group-II = Control
\end{tabular}

* Figures in the parentheses denote corresponding \%

In this study $60 \%$ patients of case group and $20 \%$ respondents of control group were hypertensive. Statistically significant difference was observed between the two groups regarding the presence of hypertension $(p=0.004)$ (Table-II).

Table II : Association of hypertension with ischaemic stroke and control groups

\begin{tabular}{lccccc}
\hline $\begin{array}{l}\text { Study } \\
\text { group }\end{array}$ & $\begin{array}{l}\text { Number of } \\
\text { Hypertensive } \\
\text { subjects }\end{array}$ & $\begin{array}{l}\text { Number of Total } \\
\text { non hypertensive } \\
\text { subjects }\end{array}$ & t value p value \\
\hline Case & $18(60) *$ & $12(40)$ & $30(100)$ & 8.297 & 0.004 \\
Control & $23(80)$ & $7(20)$ & $30(100)$ & & \\
Total & $35(58.33)$ & $25(41.66)$ & $60(100)$ & \\
\hline
\end{tabular}

* Figures in the parentheses denote corresponding \%
K Kirtania, N Sultana, S A hmed, A K hatun

The study showed that $17(56.66 \%)$ of cases and $16(53.33 \%)$ of controls were smokers. No statistically significant difference was observed between cases and controls regarding the habit of smoking (Table-III).

The mean duration of smoking was $27.41 \pm 2.98$ years in cases and $15.63 \pm 2.85$ years in controls. There was significant difference between the two groups regarding the duration of smoking (Table-IV).

Table III: Comparison of smoking habit between case and control groups

\begin{tabular}{lccccc}
\hline $\begin{array}{l}\text { Study } \\
\text { group }\end{array}$ & $\begin{array}{c}\text { Number of } \\
\text { Smoker }\end{array}$ & $\begin{array}{l}\text { N umber of } \\
\text { non Smoker }\end{array}$ & Total & t Value & p Value \\
\hline Case & $17(56.66) *$ & $13(43.34)$ & $30(100)$ & 0.067 & 0.795 \\
Control & $16(53.33)$ & $14(46.67)$ & $30(100)$ & & \\
Total & $33(55.00)$ & $27(45.00)$ & $60(100)$ & & \\
\hline
\end{tabular}

* Figures in the parentheses denote corresponding \%

Table IV: Comparison of smoking duration between case and control

\begin{tabular}{lccc}
\hline Group & $\begin{array}{c}\text { M ean duration of } \\
\text { Smoking in years }\end{array}$ & $t$ value & $p$ value \\
\hline Case $(n=17)$ & $27.41 \pm 2.98^{*}$ & 11.599 & 0.0001 \\
Control $(n=16)$ & $15.63 \pm 2.85$ & & \\
\hline
\end{tabular}

* Unpaired ' $t$ ' test was done to test significance; level of significance was 0.05

\section{Discussion}

Hypertension is one of the most important modifiable risk factors for ischemic stroke. M ost estimates for hypertension indicate a relative risk of stroke is approximately 44 . In the present study, $60 \%$ of patients with ischemic stroke and $20 \%$ of the control were hypertensive. There was highly significant difference between the two groups regarding the presence of hypertension $(p<0.01)$. Goldstein et al. (2001) found similar results in their study done in USA. They estimated $50 \%$ of patients with ischemic stroke had hypertension. The present study, showed that $56.66 \%$ of cases and $53.33 \%$ of controls were smoker. No statistically significant difference was observed between cases and controls regarding the habit of smoking 
( $p$ value> 0.50). But there was difference between the two groups regarding the duration of smoking. The mean duration of smoking was $27.41 \pm 2.98$ years in cases and $15.63 \pm 2.85$ years in control group which is statistically highly significant $(p=0.0001)$. Longer duration of smoking was associated with ischaemic stroke. Sacco et al. (1997) in their study found cigarette smoking increases the relative risk (RR) of ischemic stroke nearly two times; with a cleardose-response relation. A nother study done by Rohr et al. (996) in USA found that longer duration of cigarette smoking had the population attributable risk percent ( $95 \% \mathrm{Cl}$ intervals) for stroke among the white men was $22.6 \%$ and in the black men was $40.5 \%$ ( Rohr et al 1996).

\section{Conclusion}

A nalytical results of this study reveals that the patients of ischaemic stroke have been found to have close association with hypertension and cigarette smoking. This study suggests that hypertensive patients need measurement of blood pressure at regular interval to prevent ischaemic stroke by controlling blood pressure and give up of smoking habit.

\section{References}

1. A dams RD, Victor $M \&$ Roper $J H$. Principles of Neurology, $6^{\text {th }}$ edn, NY (USA), M C Graw -Hill, 1997

2. Fang $X H$, Kronmal RA Li SC, Longstreth $W T J r$, Cheng $X M, W$ ang $W Z$. Prevention of stroke in urban China. A community based intervention trial. Stroke 1999; 30: 495-501.

3. Danesi MA, Oneyola YA, Onitiri AC. Risk factors associated with cerebrovascular disease in Nigerian (a case control study). E Afr Med J 1983; 60: 190-95.

4. Hacke W, Kaste $M$, Bogousslavsky J, Brainin $M$, Chamorro $A \&$ Lees $K$. Ischaemic Stroke: Prophylaxis and treatment. European. Stroke Initiative, Recommendations 2003.

5. Sacco RL, Benjamin EJ, Broderick JP, D Mark, Easton JD, F einberg WM. Risk Factors of stroke. Stroke 1997; 28: 1507- 1517.

6. Golden LB, A dams R, Beeker $K$ et al. AHA stroke council, Primary Prevention of ischaemic Stroke. A statement for Healthcare Professionals from the stroke council of the American Heart A ssociation' Circulation 2001; 103: 163.

7. Rohr J, Kittner S, Feeser B et al. Traditional risk factors and ischaemic stroke in young adults: the Baltimore-Washington Cooperative Young stroke Study. Arch Neurol 1996; 53: 603-7.

8. Khan MRK. Relationship between blood lipids, lipoproteins and ischaemic stroke. M Phil Thesis 2000, BSM M U, Dhaka 